\title{
KEBIJAKAN CORPORATE SOCIAL RESPONSIBILITY (CSR) PERTAMBANGAN DAN PENGARUHNYA TERHADAP KESEJAHTERAAN MASYARAKAT \\ (Studi Kasus pada Desa Koeono, Kecamatan Palangga Selatan, Kabupaten Konawe Selatan) \\ Oleh:
}

\author{
La Ode Muhammad Elwan ${ }^{* 1}$, Irfan Ido ${ }^{2}$, La Ode Alwi ${ }^{2}$ Hendrik Wanda Putra ${ }^{3}$ \\ ${ }^{1,2}$ Dosen Universitas Halu Oleo, ${ }^{3}$ Mahasiswa Jurusan Teknik Pertambangan UHO \\ muh.elwan@uho.ac.id
}

\begin{abstract}
A research has been conducted which aims to find out how the Corporate Social Responsibility (CSR) Policy of Mining and Its Influence on Community Welfare in Koeono Village, South Palangga Subdistrict of South Konawe Regency. The data used in this research is qualitative. Determination of the number of samples taken from 110 head of household with error rate of 5\%, so get 87 respondents. The variables used in this research are CSR fund transfer mechanism, target accuracy, community involvement in CSR program planning implementation, CSR value transparency, transaction cost and monitoring and community welfare.

The results of the analysis show that the mining CSR program simultaneously have an influence on the welfare of the community. Partially, however, only CSR fund transfer mechanism variables affect the level of community welfare, while the accuracy of targets, community involvement in the implementation of CSR program planning, CSR value transparency, transaction costs and supervision does not affect the level of community welfare. Based on the determinant coefficient of percentage of influence of CSR policy on mining where CSR fund transfer mechanism, target accuracy, community involvement in CSR program implementation, transparency of CSR value, transaction cost and supervision on community welfare of Koeono Village, South Palangga Subdistrict of South Konawe Regency is $34.4 \%$, the remaining $65.6 \%$ influenced by other variables not examined in this research.
\end{abstract}

\section{Keywords : Policy, Corporate Social Responsibilty, Welfare}

\section{PENDAHULUAN}

Corporate Social Responsibility (CSR) sudah diatur dalam Undang Nomor 40 Tahun 2007 tentang Perseroan Terbatas. Pasal 74 ayat 1 Undang-undang tersebut menyebutkan bahwa "Perseroan yang menjalankan kegiatan usahanya di bidang dan/atau berkaitan dengan sumber daya alam wajib melaksanakan tanggung jawab sosial dan lingkungan". Dalam Undang-undang 25 Tahun 2007 tentang Penanaman Modal, pasal 15 (b) menyatakan bahwa "setiap penanam modal berkewajiban melaksanakan tanggung jawab sosial perusahaan". CSR merupakan perwujudan komitmen yang dibagun oleh perusahaan untuk melakukan tanggung jawab sosialnya disekitar perusahaan.

Implementasi perkembangan CSR di Indonesia masih membutuhkan banyak perhatian bagi semua pihak, baik pemerintah, masyarakat luas dan perusahaan. Di antara ribuan perusahaan yang ada, diindikasikan belum semua perusahaan benar-benar menerapkan konsep CSR dalam kegiatan perusahaannya. CSR masih merupakan bagian lain dari manejemen perusahaan, sehingga keberadaannya dianggap tidak memberikan kontribusi positif terhadap kelangsungan perusahaan. Padahal sesuai dengan UU yang ada, keberadaan CSR melekat secara inherent dengan manajemen perusahaan, sehingga bidang kegiatan dalam CSR pun masih dalam kontrol manejemen perusahaan (Freemand, 1984) dan menurut Budimanta dkk. (2008) CSR pada dasarnya merupakan suatu elemen yang penting dalam kerangka sustainability yang mencakup aspek ekonomi 
sosial budaya dan lingkungan yang merupakan proses penting dalam pengelolaan biaya dan keuntungan kegiatan bisnis dengan stakeholders baik secara internal (pekerja, shareholder, dan penanaman modal), maupun eksternal (kelembagaan, pengaturan umum, anggota-anggota masyarakat, kelompok masyarakat sipil dan perusahaan lain ).

Lebih jauh lagi dalam lingkungan bisnis perusahaan, masyarakat di sekitar perusahaan pada dasarnya merupakan pihak yang perlu mendapatkan apresiasi. Apresiasi ini dapat diwujudkan dalam bentuk peningkatan kesejahteraan hidup mereka melalui kegiatan pemberdayaan masyarakat yang dilakukan oleh kegiatan CSR perusahaan. Hal ini karena perusahaan dan masyarakat pada dasarnya merupakan kesatuan elemen yang dapat menjaga keberlangsungan perusahaan itu sendiri.

Beraneka ragam definisi CSR dan sulit diragamkan dikarenakan berbedanya pendapat parah ahli tentang definisi CSR namun secara sederhana CSR dapat dikatakan sebagai timbal balik perusahaan kepada masyarakat dan lingkungan sekitarnya karena perusahaan telah mengambil keuntungan atas masyarakat dan lingkungan sekitarnya. Dimana dalam proses pengambilan keuntungan tersebut seringkali perusahaan menimbulkan kerusakan lingkungan ataupun dampak sosial lainnya. CSR berhubungan erat dengan "pembangunan berkelanjutan" Berbagai perusahaan ditanah air terus berupaya mewujudkan tanggung jawab sosial tersebut melalui beragam program atau kebijakan kemasyarakatan serperti pengembangan agribisnis, pelatihan pengembangan UKM, kesehatan dan sanitasi, pendidikan, pembangunan infrastruktur, pelestarian alam dan budaya, serta pemberdayaan SDM.

Kecamatan Palangga Selatan merupakan salah satu lokasi beberapa peruhasahaan pertambangan nikel di Indonesia yang saat ini masih beroprasi. Perusahaan pertambangan yang beroprasi tentunya melakukan program-program CSR langsung kemasyarakat disekitar pertambangan namun setelah taahun 2016 banyak perusahaan yang tidak lagi menerapkan program CSR langsung kemasyarakat namun perusahaan memberikan dana CSR kepemerintah pusat untuk dikelola dengan program yang direncankan pemerintah pusat. Desa koeono Kecamatan Palangga selatan merupakan desa yang cukup dekat dengan lokasi pertambangan dan desa tersebut terdapat program CSR yang masih berjalan dalam bentuk program BLT (Bantuan Langsung Tunai).

Perusahaan yang beroperasi diwilayah sekitar Desa Koeono yaitu PT.Pisidefindo dan PT.Jagat Raya. Kedua perusahaan tersebut juga yang melaksanakan program CSR dalam bentuk BLT, kebijkan BLT ini dijalankan ketika perusahaan melakukan Loading yang dimana dana tersebut diberikan kepada perintah Desa kemudian dibagikan oleh bendahara Desa kepada masing-masing kepala keluarga dan jumlah uang yang diterima oleh kepala keluarga disesuaikan jarak dari perusahaan pertambangan semakin dekat maka dana CSR yang diterimah juga semakin besar begitu pun sebaliknya kepala keluarga yang jauh dari lokasi pertambangan dana CSR yang diterima pun juga semakin kecil.

Karena program CSR yang masih berjalan di Desa Koeono, Kecamatan Palangga Selatan, Kabupaten Konawe Selatan, diharapkan hubungan perusahaan dengan masyarakat trejalin baik. Sehingga dalam penelitian ini dimaksud untuk mengetahui lebih jauh program CSR yang dilakukan perusahaan pertamabangan di Desa Koeono, Kecamatan Palangga Selatan dan bagaimana pengaruhnya terhadap kesejateraan masyarakat. Berdasarkan hal tersebut maka dianggap penting untuk dilakukan penelitian dengan judul kebijakan CSR perusahaan pertambangan dan pengaruhnya terhadap kesejahteraan masyarakat Desa Koeono Kecamatan Palangga Selatan Kabupaten Konawe Selatan

\section{RUMUSAN MASALAH}

Bagaiamana kebijakan CSR Perusahaan Pertambangan di Desa Koeono Kecamatan Palangga Selatan, Kabupaten Konawe Selatan? 


\section{TINJAUAN PUSTAKA}

\section{A. Konsep Kebijakan}

Kebijakan di sektor pemerintah disebut kebijakan publik. Kraft \& Furlong (2004:4) mengemukakan bahwa kebijakan publik dapat didefinisikan dalam beragam cara, tetapi pada dasarnya adalah suatu cara tindakan pemerintah (atau tidak bertindaknya pemerintah) yang diambil sebagai respons terhadap masalah-masalah sosial. Masalah sosial adalah kondisi-kondisi yang dipahami secara umum oleh publik sebagai sesuatu yang tidak dapat diterima dan karena itu memerlukan intervensi.

Easton dalam Mulyadi (2015) mendefinisikan kebijakan publik sebagai pengalokasian nilai-nilai kepada seluruh masyarakat secara keseluruhan. Sementara Mulyadi (2015) menyebutkan bahwa kebijakan publik merupakan rumusan keputusan pemerintah yang menjadi pedoman guna mengatasi masalah publik yang mempuyai tujuan rencana dan program yang aka dilaksanakan secara jelas. Kesimpulannya : (1). Kebijakan publik adalah tentang pilihan: pilihan atas tujuan-tujuan; pilihan atas alasan untuk dan di dalam bertindak; pilihan atas instrumen-instrumen; pilihan tentang bagaimana merespon konsekuensi-konsekuensi dari outputs kebijakan (2) Kebijakan pubik pada dasarnya adalah suatu keputusan yang dimaksudkan untuk mengatasi kesalahan, tertentu melakukan kegiatan tertentu atau untuk mecapai tujuan tertentu yang dilakukan oleh institusi yang berwenang dalam rangka penyelenggraaan tugas pemerintahan negara dan pembangunan, berlangsung dalam suatu kebijakan tertentu.

Wilson (2006:12) menyatakan bahwa elemen yang lazim dalam definisi kebijakan publik adalah "suatu proses atau rangkaian atau pola dari aktivitas atau keputusan-keputusan pemerintahan yang didesain untuk memecahkan sejumlah masalah publik. Kebijakan publik merefleksikan maksud, tujuan-tujuan, dan nilai-nilai dari pemerintah. ICAEW (2012:10) menyatakan bahwa kepentingan publik adalah segala sesuatu yang dipentingkan bagi publik. Masalahnya, hal-hal yang bermanfaat bagi publik tidak selalu persis sama dengan apa yang mereka anggap penting. Labih lanjut menyatakan bahwa kepentingan publik dapat didefinisikan dari tiga perspektif. Pandangan rasionalis mengatakan bahwa kepentingan publik adalah kepentingan terbanyak dari total penduduk yang ada. Pandangan idealis mengatakan bahwa kepentingan publik itu adalah hal yang luhur sehingga tidak boleh direka-reka oleh manusia. Pandangan realis mengatakan bahwa kepentingan publik itu adalah hasil kompromi dari bertarungan berbagai kelompok kepentingan.

\section{B. Corporate Social Responsibility (CSR)}

Corporate Social Responsibility adalah suatu kebijakan yang diterapkan dimasyarakat guna mengurangi dampak negatif yang diakibatkan perushaan. CSR juga berhubungan erat dengan "pembangunan berkelanjutan"dimana hal ini sudah tercantum dalam UUPT No. 40 tahun 2007 pasal 1 angka 3 menyebutkan TJSL adalah komitmen Perseoran untuk berperan dalam pembangunan ekonomi berkelanjutan guna meningkatkan kualitas kehidupan dan lingkungan yang bemanfaat, baik bagi persoran sendiri, komunitas setempat, maupun masyarakat pada umumnya.

Corporate Social Responsibility juga besar peranannya dalam meningkat perekonomian masyarakat disekitar perusahaan. Howar R.Bowen pada tahun 1953 (Carrol, 1999) dalam karyanya "Social Resposibilities of the Business" yang merumuskan konsep tanggung jawab sosial sebagai "The Obligations of businessman to pursue those policies, to make those decisions, or to follow those line of action which are desirable in term of the objectives and values ofour sociat". Merujuk pada Jalal (2010) dalam Nasdian (2014) bahwa tanggung jawab sosial perusahaan merupakan upaya manajemen yang dijalankan oleh perusahaan berdasarkan keseimbangan pilar 
ekonomi, sosial dan lingkungan dengan meminimumkan dan mengkompensasi dampak negatif serta memaksimalkan dampak positif setiap pilar.

\section{CSR Perusahaan Di Bidang Pertambangan}

Usaha pertambangan dalam konteks pembangunan berkelanjutan adalah tranformasi sumber daya tidak terbarukan (Non renewable resources) menjadi sumber daya pembangunan terbarukan (Non renewable resources). Hal yang menjadi peningkatan nilai tambah (PNT) pertambangan harus berbasis sumber daya setempat atau nasional (local resourse based), berbasis masyarakat (community based), dan berkelanjutan (sustainable). PNT pertambangan sebagai Action plan pembangunan pertambangan yang berkelnjutan, pada dasarnya merupakan implementasi kegiatan konservasi pertambangan, yaitu dalam hal keberlanjutan manfaat ekonomi dan lingkungan sosial kemasyarakatan yang diperoleh semenjak perencanaan, selam berlangsungnya kegiatan pertambangan sampai dengan pasca tambang. (Suyartono, 2003).

Secara umum tujuan dilakukan CSR pada perusahaan tambang adalah :

1. Meningkatkan kesejahteraan masyarakat sekitar lokasi tambang;

2. Pengusaha dapat melaksanakn kegiatan penambangan tampa mengalami gangguan yang dapat menghambat usaha pertambangan;

3. Merasang pengembangan ekonomi masyarakat local dengan memanfaatkan keberadaan perusahaan tambang sebagai pijakan awal proses pertumbuhan;

4. Menciptakan masyarakat yang mandiri dan memiliki kemampuan setelah berakhirnya masa penambangan (paska tambang).Melakukan kajian yang terkait dengan adanya kegiatan penambangan mulai dari sebelum penambangan, pada saat operasional penambangan dan berakhirnya masa penambangan.

\section{Penerapan CSR}

Penerpan program CSR merupakan salah satu bentuk implementasi dari konsep tata kelola perushaan yang baik. Diperlukan tata kelola perushaan yang baik agar prilaku para pelaku bisnis mempunyai arahan sosial dirujuk dengan mengatur hubungan dengan masyarakat dan para stakeholder.

Menurut Wibisono (2007) perusahaan yang telah berhasil dalam menerapkan CSR menggunakan tahapan sebagai berikut:

\section{Tahap Perencanaan}

Awareness Builiding merupakan langkah awal untuk membangun kesasadaran mengenai arti penting CSR dan komitmen manejemen.Upaya ini dapat dilakukan antara lain melalui seminar,lokakarya, diskusi kelompok dan lain-lain. Corporate Social Responsibility Assessement merupakan upaya untuk memetakan kondisi perusahaan dan mengidentifikasi aspek-aspek yang perlu mendapatkan prioritas perhatian dan langkah-langkah yang tepat untuk membangun struktur perusahaan yang kondusif bagi penerapan CSR secara efektif. Langkah selanjutnya adalah membangun CSR manual. Hasil penilaian merupakan dasar penyusunan menual atau pedoman implementasi CSR. Upaya yang mesti dilakukan antara lain melalui benchmarking, menggali dari referensi atau bagi perusahaa yanng menginginkan langkah praktis, penyusunan manual ini dapat dilakukan dengan meminta bantuan tenaga ahli independen dari luar perusahaan. Penyusunan manual ini merupakan inti dari perencanaan kerena memberikan petunjuk pelaksanaan CSR bagi komponen perusahaan. Penyusunan manual CSR dimuat sebagai pedoman dalam pengelolaan kegiatan-kegiatan sosial kemasyarakatan yang dilakukan oleh perusahaan. Pedoman ini diharapkan mampu memberikan kejelasan dan keseragaman pola pikir dan pola tindak seluruh elemen perusahaan guna tercapainya program yang terpadu, efektif dan efesien. 


\section{Tahap Implementasi}

Perencanaan sebaik apapun tidak akan berdampak apapun bila tidak diaplikasikan dengan sungguh-sungguh. Sehingga tujuan CSR secara keseluruhan tidak akan tercapai, dan masyarakat tidak merasakan manfaat optimal sementara anggaran yang telah dikeluarkan tidak kecil. Oleh karena itu, perlu disusun strategi untuk menjalankan rencana yang telah dirancang.

Tahap implementasi terdiri atas tiga langkah utama yakni sosialisasi, pelaksanaan dan internalisasi. Sosialisasi diperlukan untuk memperkenalkan berbagai aspek yang terkait dengan implementasi CSR khususnya mengenai pedoman penerapan CSR. Tujuan utama sosialisasi ini adalah program CSR mendapat dukungan penuh dari seluruh komponen perusahaan, sehingga dalam pelaksanaannya dapat berjalan lancar.

Pelaksanaan kegiatan yang dilakukan pada dasarnya harus sejalan dengan pedoman CSR yang ada, berdasarkan pada roadmapyang telah disusun. Sedangkan internalisasi adalah tahap jangka panjang.

Internalisasi mencakup upaya-upaya memperkenalkan CSR di dalam seluruh proses bisnis perusahaan misalnya melalui system manejemen kinerja, prosedur pengandaan, proses produksi, pemasaran dan proses bisnis lainnya. Sehingga Penerapan CSR menjadi strategi perusahaan bukan lagi sebagai upaya untuk compliance tapi sudah beyond compliance.

\section{Tahap Evaluasi}

Setelah program CSR diimplementasikan, langkah berikutnya adalah evaluasi program. Tahap evaluasi adalah tahap yang diperlukan secara konsisten dari waktu untuk mengukur sejauh mana efektifitas penerapan CSR. Evaluasi dilakukan untuk pengambilan kebijakan. Misalnya kebijakan untuk menghentikan, melanjutkan atau memperbaiki dan mengembangkan aspek-aspek tertentu dari program yang telah diimplementasikan.

Evaluasi juga bisa dilakukan dengan meminta pihak independen untuk melakukan audit implementasi atas praktik CSR yang telah dilakukan. Langkah ini tidak terbatas pada kepatuhan terhadap peraturan dan prosedur operasi standar tetapi juga mencakup pengendalian resiko perusahaan. Evaluasi dalam bentuk assessement audit atau scoring juga dapat dilakukan secara mandatory.

\section{Tahap Penerapan}

Pelaporan diperlukan dalam rangka membangun system informasi baik untuk keperluan proses pengambilan keputusan maupun keperluan keterbukaan informasi material yang relevan mengenai perusahaan. Jadi selain berfungsi untuk keperluan shareholder juga untuk stakeholder lainnya yang memerlukan.

Penelitian-penelitian yang dilakukan mengenai pelaksanaan CSR didunia pertambangan, baik pada skala internasional maupun secara terbatas di Indonesia menyimpulkan bahwa pada umumnya perusahaan tambang sudah memiliki pemahaman yang cukup mendalam tentang CSR dan industry tambang sudah melaksanakannya dengan cukup luas melalui program-program pengembangan masyarakat (community development). Alasan perusahaan dalam melakukan pengungkapan informasi CSR secara sukarela telah diteliti. Diantaranya adalah karena untuk mentaati peraturan yang ada dan untuk memperoleh keunggulan kompotitif melalui penerapan CSR untuk memenuhi ketentuan kontrak pinjaman dan memenuhi ekspektasi masyarakat untuk melegitimasi tindakan perusahaan dan menarik investor (Sayekti dan Wondabio. 2007)

\section{Tolak Ukur Keberhasilan Program CSR}

Menurut Gunawan (2009), Dewan Pengawas Konsorsium CSR dalam sebuah pelatihan CSR awal tahun ini mengatakan bahwa dalam melaksanakan CSR, setiap individu yang terlibat harus sadar untuk memiliki PSR (Personal Social Responsibility). Dengan cara sederhana ini, setiap orang akan secara otomatis memiliki kesadaran akan tanggung jawab sosial dalam suatu organisasi/perusahaan. CSR ini harusnya ditekankan oleh setiap perusahaan untuk membangun kemampuan karyawannya, sehingga terlibat secara penuh dalam 
kegiatan CSR. Sering kali yang menjadi sorotan pelaku bisnis adalah keuntungan yang diperoleh jika melaksanakan CSR.

Alat untuk mengukur keberhasilan CSR sangat sulit, memang pada kenyataannya tidak ada cara untuk mengukur tingkat keberhasilan program CSR secara pasti, karena itu masing-masing perusahaan akan mempunyai target-target sendiri untuk melihat suksesnya program CSR, yang terpenting sasaran utama peningkatan kesejahteraan masyarakat sekitar menjadi tolak ukur utama dalam menjalankan program CSR perusahaan. Masyarakat menjadi evaluator yang kompeten, karena memiliki kepentingan cukup besar.

Pada kenyataannya, banyak program-program CSR yang tidak berhasil, meskipun usaha yang dilakukan untuk menerapkan program tersebut sudah optimal namun hasil yang dicapai masih belum maksimal. Kendalakendala dalam pelaksanaan program tersebut harus dianalisis secara cermat. Setiap perusahaan menghadapi kendala masing-masing. Situasi disesuaikan dengan indikator-indikator yang terkait dengan perusahaan tersebut.

Sebelum membuat program CSR harus dilakukan penelitian. Biaya yang dialokasikan memang cukup besar, tetapi penelitian lapangan terkait dengan program CSR yang akan dilakukan harus dilaksanakan supaya kebutuhan para stakeholder dapat diakomodir, sehingga program CSR yang akan diimplentasikan tidak salah sasaran dan memberi manfaat secara berkelnajutan.

\section{E. Corporate Social Responsibility Yang Ideal}

Harapan dan tujuan ideal dari peranan CSR perusahaan dalam kehidupan sosial kemasyarakatan. Menurut Kim (2000) praktek CSR perusahaan dapat diidentifikaskan dalam berbagai tujuan, yakni hukum, ekonomi, moral, dan filantropi. Namun demikian, tujuan tersebut masih dapat dikembangkan sesuai dengan kondisi aktual di masyarakat terkait dengan tekanan yang terjadi dalam kehidupan masyarakat. Salah satu tujuan CSR yang sangat urgen khususnya di negara sedang berkembang adalah peningkatan kualitas pendidikan masyarakat. Oleh karena itu penerapan CSR di Indonesia pada dasarnya dapat diarahkan pada penguatan ekonomi rakyat yang berbasis usaha kecil dan menengah serta peningkatan kualitas SDM masyarakat melalui perbaikan sarana dan prasarana pendidikan.

\section{F. Kesejahteran Masyarakat}

Undang-Undang Republik Indonesia No.1l tahun 2009 Tentang Kesejahteraan Sosial Pasal l bahwa Kesejahteraan Sosial adalah kondisi terpenuhinya kebutuhan material, spiritual, dan sosial warga negara agar dapat hidup layak dan mampu mengembangkan diri, sehingga dapat melaksanakan fungsi sosialnya. Penyelenggaraan Kesejahteraan masyarakat adalah upaya yang terarah, terpadu, dan berkelanjutan yang dilakukan pemerintah, pemerintah daerah, dan masyarakat dalam bentuk pelayanan sosial guna memenuhi kebutuhan dasar setiap warga negara, yang meliputi rehabilitasi sosial, jaminan sosial, pemberdayaan sosial, dan perlindungan sosial (Gunawan, 2009). Secara umum tingkat kesejahteraan masyarakat dapat dicermati dari rumah, kesehatan, pendidikan dan daya beli. Rumah, jika merujuk teori Maslow. Rumah adalah kebutuhan utama yang harus terpenuhi sebelum menginjak ke tingkat kesejahteraan selanjutnya, memiliki rumah berarti memiliki tempat untuk bermukim. Jika seseorang tidak mempunyai rumah maka akan menyewa rumah, menumpang, bahkan menjadi gelandangan. Kesehatan, yang sering terjadi dikalangan masyarakat kurang sejahtera adalah gizi buruk. Pendidikan adalah kunci untuk menjadi sejahtera.Terbukti kebanyakan warga Indonesia tidak bisa melanjutkan ke perguruan tinggi karena kendala keuangan. Mayoritas masyarakat berhenti bersekolah di Sekolah Menegah Atas (SMA). Daya beli, kesejahteraan masyarakat juga bisa dicermati dari kemampuan daya beli masyarakat tersebut terhadap kebutuhan pokok maupun kebutuhan lainnya, seperti mobil, barang berharga dan lain-lain (Dahlia dan Siregar, 2008). 


\section{KERANGKA PIKIR PENELITIAN}

Penelitian ini bertujuan untuk mengetahui program CSR pertambagan yang dimana dalam pelaksanaan program CSR terdapat mekanisme transfer dana CSR, ketepatan sasaran CSR, keterlibatan masyarakat dalam pelaksanaan perencanaan program CSR dan trasparansi nilai CSR apakah ada pengaruhnya terhadap kesejahteraan masyarakat dengan mengacu pada penelitian terdahulu maka kerangka teoritis dalam penelitian ini memadukan variabel mekanisme transfer dana CSR, ketepatan sasaran CSR, keterlibatan masyarakat dalam pelaksanaan perencanaan program CSR dan transparansi nilai CSR yang mempunyai mempengaruhi terhadapa kesejahteraan masyarakat. Kerangka penelitian ini digunakan untuk mempermudah jalan pemikiran terhadap masalah yang akan dibahas. Adapun kerangka konseptual yang dikembangkan dalam model ini adalah sebagai berikut :



Gambar 1. Kerangka Pikir

\section{METODE PENELITIAN}

Penelitian ini telah dilaksanakan di di desa Koeono Kecamatan Palangga Selatan, Kabupaten Konawe Selatan. Desa Koeono dipilih menjadi lokasi penelititian dikarenakan di Desa tersebut terdapat program CSR pertambangan yang masih berjalan di Kecamatan Palangga Selatan, Kabupaten Konawe Sealatan. Penelitian ini menggunakan metode kuantitatif, dimana metode kuantitatif ini bertujuan untuk mengangkat fakta, keadaan variabel, dan fenomena-fenomena yang terjadi saat sekarang dan menyajikan apa adanya (Sugiono 2004).

Populasi adalah wilayah generalisasi terdiri dari atas Objek/subjek yang mempunyai kualitas dan karakteristik tertentu yang ditetapkan oleh penelitian untuk dipelajari kemudian ditarik kesimpulan (Sugiono 2012). Populasi dalam penelitian ini adalah masyarakat di Desa Koeono, Kecamatan Palangga Selatan, Kabupaten Konawe Selatan yang berada disekitar pertambangan. Dimana jumlah populasi untuk Desa Keono $110 \mathrm{KK}$.

Demi memudahkan Peneliti untuk meneliti maka akan ditentuakan sampel dari populasi tersebut. Sampel adalah sebagian populasi yang diambil sebagai sumber data dan dapat mewakili seluruh populasi. Metode 
pengambilan sampel dilakukan dengan menggunakan teknik simple random sampling, yaitu metode penentuan sampel yang dilakukan secara acak. (Sugiyono, 2004). Maka dapat ditentukan jumlah sampel yang dihitung dengan menggunakan rumus Slovin yang dikemukakan oleh Riduwan (2009). Dengan alat penduga (tingkat kesalahan) sebesar $5 \%$ maka dapat mengunakan rumus sebagai berikut:

Dimana:

$\mathrm{n}=$ Jumlah sampel

$\mathrm{N}=$ Jumlah populasi

$\mathrm{e}=$ Galat penduga $(0,05)$

Berdasarkan rumus Slovin yang dikemukakan oleh Riduwan (2009), maka jumlah sampel yang didapat adalah 86,275 atau dibulatkkan menjadi 87 KK masyarakat sebagai responden penelitian di Desa Koeono.

\section{Uji Validitas, Uji Reliabilitas dan Analisis Regresi Berganda}

Data yang diperoleh berupa jawaban dari masyarakat terhadap pertanyaan atau butir-butir yang diajukan. Untuk itu perlu dilakukan uji validitas dan uji reliabilitas terhadap butir-butir pertanyaan dalam kuesioner agar data yang diperoleh dari pengukuran jika diolah tidak memberikan hasil yang menyesatkan. Selanjutnya dalam menganalisis Regresi berganda menggunakan uji secara simultas (uji $F$,) dan secara parsial (uji T). uji signifikansi simultan digunakan untuk menunjukkan apakah semua variabel bebas yang dimasukkan dalam model mempunyai pengaruh secara bersama-sama terhadap variabel terikat, sehingga dalam penelitian ini uji $F$ digunakan untuk mengetahui hubungan antara variabel independent dan variabel dependent. Uji parsial digunakan untuk menguji masing-masing variabel berarti atau tidaknya hubungan variabel-variabel independent mekanisme transfer dana CSR (X1), ketepatan sasaran CSR (X2), keterlibatan masyarakat dalam pelaksanaan perencanaan program CSR (X3), dan transpransi nilai CSR (X4)dengan variabel dependen yaitu kesejahteraan masyarakat (Y).

\section{PEMBAHASAN}

\section{A. Deskripsi Wilayah Penelitian}

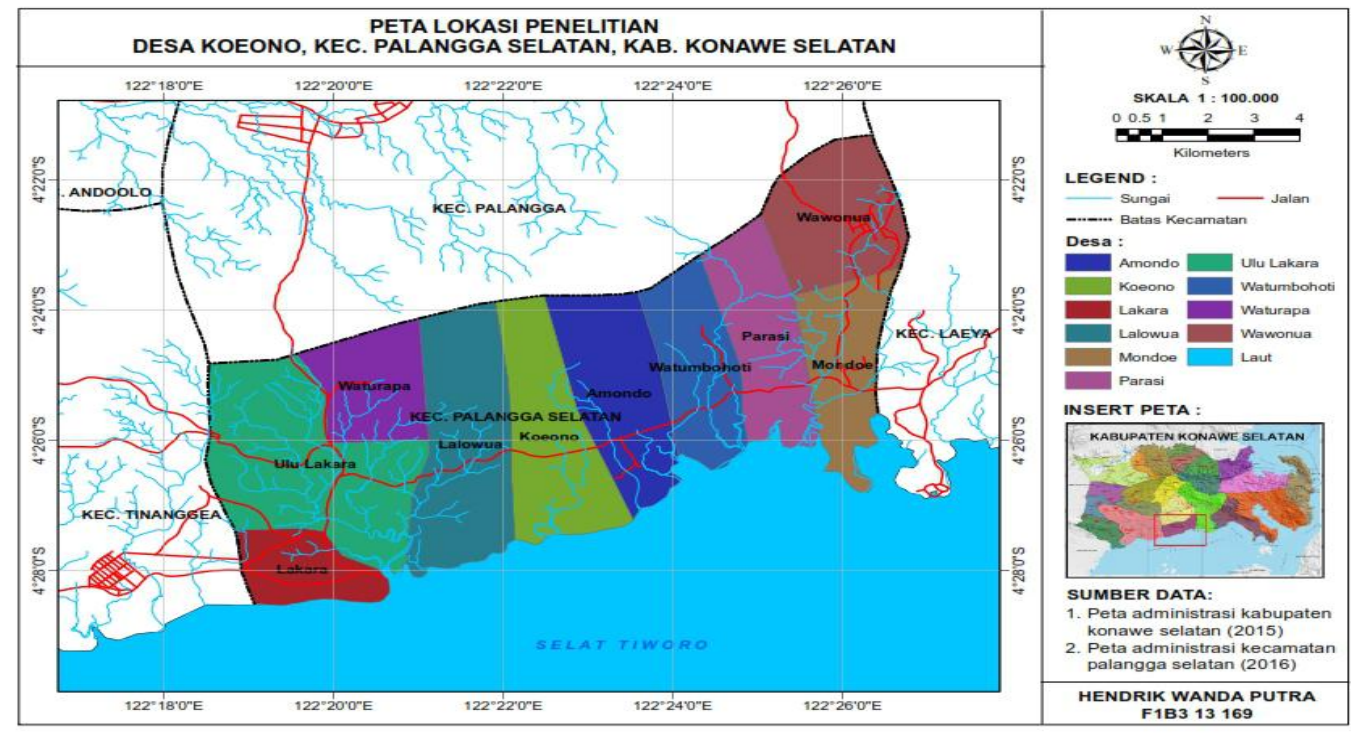

Gambar 2. Peta lokasi penelitian

Desa Koeono salah satu desa yang masuk dari lokasi pertambangan di Kecamatan Palangga Sealatan Kabupaten Konawe Selatan yang mempunyai luas wilayah sebesar $1106 \mathrm{Ha}$ atau 6,38 persen dengan jumlah penduduk sebanyak 529 jiwa/orang. 
Tabel 1. Keadaan sarana dan prasarana sosial desa Koeono Kec.Palangga Selatan Konawe Selatan

\begin{tabular}{|c|l|c|c|}
\hline No. & Sarana dan Prasarana & Jumlah Fisik (unit) & Keterangan \\
\hline 1. & SD & 1 & Baik \\
\hline 2. & Sumur Bor & 7 & Baik \\
\hline 3. & Masjid & 1 & Baik \\
\hline 4. & Posyandu & 1 & Baik \\
\hline 5. & Kantor Desa & 1 & Baik \\
\hline 6. & Balai Desa & 1 & Baik \\
\hline 7. & Sangar PKK & 1 & Baik \\
\hline
\end{tabular}

Sumber: Data Desa koeono Tahun 2017

\section{B. Kondisi Kebijakan CSR Pertambangan di Desa Koeono}

Kibijakan CSR di Desa Koeono saat penelitian adalah kebijakan CSR dalam bentuk program BLT (Bantuan Langsung Tunai) dengan mekanisme program perusahaan mengeluarkan dana CSR berdasar hitungan 50 ribu perton pada saat loading (pengangkutan) kemudian jumlah uang tersebut diberikan kepada pemerintah Desa yang dikolola oleh bendahara Desa dan dibagikan keseluruh kepala keluarga di Desa Koeono. Aturan dalam pembagian dana program BLT atau yang biasa masyarakat kenal dengan istilah uang dampak yaitu kepala keluarga yang paling dekat dengan lokasi pertambangan atau dekat dengan aktivitas pertambangan maka akan menerima uang program BLT dengan jumlah paling besar kemudian dipotong sebesar Rp 20.000 untuk perawatan mesjid (keadaan mesjid lampiran 8) yang berada di Desa Koeono sedangkan untuk kepala keluarga yang berada jauh dari lokasi aktivitas tambang akan menerima dana BLT paling sedikit dan juga mendapatkan potongan untuk pembangunan masjid, namum untuk kepala keluarga yang bekerja sebagai nelayan di Desa koeono mereka menerima dana BLT dengan cara merata atau jumlah dana yang diterima sama tidak melihat dari jarak tempat tinggal kepala keluarga.

Tabel 2. Kelompok Pembangian Dana BLT

\begin{tabular}{|l|c|}
\hline Kelompok Pembangian Dana BLT & Dana yang diterima \\
\hline $100 \mathrm{~m}$ dari Hauling Road ( Jalan Angkut Pertambangana) & Rp.400.000 \\
\hline $200 \mathrm{~m}$ dari Hauling Road ( Jalan Angkut Pertambangana) & Rp. 300.000 \\
\hline $300 \mathrm{~m}$ dari Hauling Road ( Jalan Angkut Pertambangana) & Rp.200.000 \\
\hline $400 \mathrm{~m}$ dari Hauling Road ( Jalan Angkut Pertambangana) & Rp.100.000 \\
\hline
\end{tabular}

Sumber: Data Primer, diolah 2017.

CSR merupakan komitmen perusahaan atau dunia bisnis untuk berkontribusi dalam pengembangan ekonomi yang berkelanjutan dengan memperhatikan tanggung jawab sosial perusahaan dan menitikberatkan pada keseimbangan antara aspek ekonomi, sosial, dan lingkungan (Untung, 2008:1). Berdasarkan pernyataan terasebut, maka hasil penelitian di Desa Koeono dapat dikatakan kebijakan CSR nya belum ideal dikarenakan belum ada kebijakan CSR yang membuat masyarakat dapat mandiri dalam bidang ekonomi demi terwujudnya pemgembangan ekonomi berkelajuntan. Masyarakat Seharusnya dibuat mandiri dalam bidang ekonomi dikarenakan perusahaan pertambangan yang sifatnya sementara, jika masyarakat tidak mandiri dalam hal ekonomi maka saat pertambangan sudah tidak beropersi lagi masyarakat akan kembali susah dalam perekonomiannya. Kemandirian ekonomi untuk masyarakat dapat diwujudkan dengan kebijkan CSR yang dapat diarahkan pada penguatan ekonomi rakyat yang berbasis usaha kecil dan menengah serta peningkatan kualitas SDM masyarakat melalui perbaikan sarana dan prasarana pendidikan. 


\section{Uji regresi linier berganda}

\begin{tabular}{|c|c|c|c|c|c|}
\hline \multirow[t]{3}{*}{ Coefficients ${ }^{\mathrm{a}}$} & & & & \multirow[b]{3}{*}{$\mathrm{t}$} & \multirow[b]{3}{*}{ Sig. } \\
\hline & \multicolumn{2}{|c|}{$\begin{array}{l}\text { Unstandardized } \\
\text { Coefficients }\end{array}$} & \multirow{2}{*}{\begin{tabular}{c|}
$\begin{array}{c}\text { Standardized } \\
\text { Coefficients }\end{array}$ \\
Beta
\end{tabular}} & & \\
\hline & $\mathrm{B}$ & Std. Error & & & \\
\hline (Constant) & 30.311 & 8.053 & & 3.764 & .000 \\
\hline - Mekanisme Transfer dana CSR & .512 & .106 & .527 & 4.838 & .000 \\
\hline - Ketepatan sasaran & .021 & .097 & .026 & .217 & .829 \\
\hline -Keterlibatan_masyarakat_dalam_perencanaanprogram_CSR & -.206 & .123 & -.183 & -1.673 & .098 \\
\hline - Transparansi dana CSR & .175 & .096 & .178 & 1.829 & .071 \\
\hline $\begin{array}{l}\mathrm{F}=9.667 \text { dan nilai signifika }=0.000 \\
\mathrm{R}^{2}=0.320 \text { atau } 32 \%\end{array}$ & & & & & \\
\hline
\end{tabular}

Berdasarkan tabel diatas dapat diperoleh persamaan regresi berganda sebagai berikut:

$\mathrm{Y}=30.31+0,512 \mathrm{Xl}+0,021 \mathrm{X} 2-0,206 \mathrm{X} 3+0,175 \mathrm{X} 4$

\section{PENGARUH KEBIJAKAN CSR PERTAMBANGAN TERHADAP KESEJAHTERAAN MASYARAKAT}

1. Pengaruh mekanisme transfer dana CSR terhadap kesejahteraan measyarakat.

Mekanisme transfer dana CSR mempunyai pengaruh cukup penting dalam pelaksanaan program CSR. Menurut masyarakat mekanisme transfer dana yang dilakukan di Desa Koeono sudah cukup baik dengan dana CSR yang diberikan perusahaan kepada Pemerintah Desa kemudian dikelola oleh bendahara Desa dengan membagikan kepada ketua RT, ketua RT membagikan kepada masing kepala keluarga.

2. Pengaruh ketepatan sasaran CSR terhadap kesejahteraan masyarakat.

Batuan CSR yang diberikan kepada masyrakat tidak dilihat dari masyarakat yang paling membutuhkan namun dilihat dari jarak terdekat dengan tambang, semakin dekat dengan lokasi tambang maka batuan yang diterimah semakin besar, sehingga masyrakat yang kurang mampu dan bertempat tinggal jauh dari lokasi tambang akan sulit untuk sejahtera.

3. Pengaruh keterlibatan masyarakat dalam pelaksanaan perencanaan program CSR terhadap kesejahteraan masyarakat

keterlibatan masyarakat dalam pelaksanaan perencanaan program CSR tidak mempunyai pengaruh terhadap kesejahteraan masyarakat. Hal ini dikarenakan jika seluruh masyarakat dilibatkan dalam peleksanaan perencanaan program CSR hanya akan menimbulkan pendapat-pendapat yang bertujuan untuk mendapatkan keuntungan yang sifatnya individu sehingga tujuan untuk mensejahterakan masyarakat sulit dicapai.

\section{Pengaruh transparansi nilai CSR terhadap kesejahteraan masyarakat}

transparansi nilai CSR tidak mempunyai pengaruh terhadap kesejahteraan masyarakat. Hal ini dikarenakan banyak masyarakat yang mengangap bantuan program CSR yang mereka terimah tidak cukup transparan yang dimana nilai dana CSR yang mereka terimah tidak disosialisasikan sebelumnya dari perusaahaan, namun masyarakat hanya langsung mnenerimah dari ketua RT tanpa mengatahui jumlah sesungguhnya dari perusahaan. Sehingga dapat dikatakan variabel transparansi nilai CSR tidak cukup berpengaruh akan kesejahteraan masyarakat. 


\section{KESIMPULAN}

Berdasarkan tabel diatas dapat diperoleh persamaan regresi berganda sebagai berikut:

$\mathrm{Y}=30.31+0,512 \mathrm{Xl}+0,021 \mathrm{X} 2-0,206 \mathrm{X} 3+0,175 \mathrm{X} 4$

Berdasarkan analisis regresi linier berganda, maka dapat dilihat bahwa yang paling berpengaruh terhadap variabel kesejahteraan masyarakat adalah variabel mekanisme transfer dana CSR dengan nilai koefisien regresi sebesar 0,512 (51,2\%). Variabel ketepatan sasaran CSR berpengaruh positif tetapi tidak signifikan dengan nilai koefesien regresi sebesar 0,021 (2,1\%). Variabel Transparansi nilai CSR berpengaruh positif tetapi tidak signifikan dengan nilai koefesien regresi sebesar 0,175 (17,5 persen). Sedangkan variabel keterlibatan masyarakat dalam pelaksanaan perencanaan program CSR tidak berpengaruh positif dan juga tidak signifikan terhadap kesejahteraan masyarakat dengan nilai koefesien regresi -0,216 (21,6\%).

Pada pengujian hipotesis dengan menggunakan uji $\mathrm{F}$ (secara bersam sama atau smultan) dapat dijelaskan bahwa kelima svariable yaitu mekanisme transfer dana CSR (Xl), ketepatan sasaran (X2), keterlibatan masyarakat dalam pelaksanaan perencanaan program CSR (X3), dan transparansi nilai CSR (X4) secara bersama-sama berpengaruh terhadap variabel kesejahteraan masyarakat. $\mathrm{Hal}$ ini ditunjukkan dari nilai $\mathrm{F}$ hitung sebesar 9,667 dengan angka signifikansi (P Value) sebesar 0,000<0,05. Sedangkan pengujian Secara Uji t (secara masing-masing atau parsial) hanya variabel mekanisme transfer dana CSR yang berpengaruh terhadap tingkat kesejahteraan masyarakat yang dimana nilai signifikannya $0,000<0.05$ dan variabel ketepatan sasaran CSR, keterlibatan masyarakat dalam pelaksanaan perencanaan program CSR, dan transpransi nilai CSR yang semuanya tidak berpengaruh pada kesejahteraan masyarakat di Desa Koeono dikarenakan nilai signifikannya $>0.05$.

\section{SARAN}

Berdasarkan hasil penelitian dan uraian dalam pembahasan, maka dapat disimpulkan sebagai berikut :

1. Bagi masyarakat, program CSR yang diberikan dari perusahaan seharusnya masyarakat lebih terlibat dalam perencanaan mau pelaksanaan program CSR, agar masyarakat lebih memahami dan mengatahui mekanisme transfer dana CSR tersebut sehingga bisa melakukan pengawasan dan tidak dirugikan atau pun dimanfaatkan oleh pihak-pihak yang tidak bertanggung jawab demi mendapatkan keuntungan dari masyarakat.

2. Bagi perusahaan, dalam program CSR sebaiknya mekanisme transfer dana CSR yang sudah baik diusahakan lebih baik lagi, dibuat lebih tepat sasaran, lebih transpransi untuk dana CSR dan melakukan pengawasan sehingga dalam palaksanaan program CSR dapat dilihat apakah mencapai tujuan untuk program tersebut atau tidak.

3. Bagi Pemeritahan, agar lebih transpransi, lebih tepat sasaran dan melakukan pengawasan sehingga peran dari pemerintah dirasakan oleh masyarakat melalui program CSR yang dimana bertujuan untuk mensejahterakan masyarakat. 


\section{DAFTAR PUSTAKA}

Algifari. 2001. Analisis Regresi. Yogayakarta : BPFE

Budimanta, Arif, Adi Prasetyo, dan Bambang Rudito. 2008. Corporate Social Responsibility: Alternatif bagi Pembangunan Indonesia. Jakarta:ICSD.

Carrol, Archie B, 1999, The Pyramid Of Corporate Social Responbility: Tower The Moral Manegement of Organizational Stakeholders, Business Horizon.

Dahlia, D. dan Siregar. 2008. Pengaruh Corporate Social Responsibility Terhadap Nilai Perusahaan Dengan Profitabilitas Sebagai Variabel Moderating (Studi Empiris pada Perusahaan Manufaktur yang terdaftar di Bursa Efek Indonesia). Skripsi.Program Sl Fakultas Ekonomi Universitas Diponegoro. Semarang.

Gunawan, 2009.Personal Social Responsibility. Bandung: Universitas Padjadjaran.

Jalal. 2010 .Pembagunan Berkelanjutan, CSR dan ISO 26000. Pelatihan ISO 26000 Bogor, 24-25 Maret 2010. Bogor CSR/A + CSR Indonesia. http://www.csrindonesia.com/data/articles/20100329054244-a.pdf.

Kim, K.S. 2000. Corporate Social Responsibility And Strategic Management : An Empirical Study of Korean MNCs in The United States. Unpublished Dissertation. West Heaven, Connecticut: The University Of Heaven.

Kraft, Michael E., Scott R. Furlong, 2004. Public Policy: Politics, Analysis, and Alternatives. Washington: CQ Press.

Mulyadi, D. 2015. Studi Kebijakan Publik dan Pelayanan Publik : Konsep dan Aplikasi Proses Kebijakan Publik dan Pelayanan Publik. Bandung : Alfa Beta.

Riduwan. 2009. Aplikasi Statistik dan Metode Penelitian Untuk Administrasi dan Manajemen. Bandung : Dewa Ruci.

Sayekti, Y . adan L. S. Wondobio. 2007. Pengaruh CSR Disclosure Terhadap Earning Response Coefficient. Simposium Nasional Akutansi X. Makassar, 26-28 juli.

Sugiyono. 2004. Metode Penelitian Bisnis: Penerbit CV. Alfabeta: Bandung.

Suyartono, 2003, Good Mining Practice, Konsep Tentang Pengelolaan Pertambangan Yang Baik Dan Benar. Semarang: Studi Nusa.

Wibisono, Yusuf. 2007. Membedah Konsep Dan Aplikasi Corporate Social Responsibility. Gresk: Fascho Publishing.

Wilson, Charter A., 2006. Public Policy: Continuity and Change. New York: McGraw-Hill. 